\title{
Renal coloboma syndrome
}

INSERM

\section{Source}

INSERM. (1999). Orphanet: an online rare disease and orphan drug data base. Renal coloboma syndrome. ORPHA:1475

Renal coloboma syndrome (RCS) is a genetic condition characterized by optic nerve dysplasia and renal hypodysplasia. 